\title{
Manisa Yazma Eserler Kütüphanesi'nde Bulunan Mushaf-ı Şerîf'lerin Serlevha Bezemelerinden Örnekler
}

Belgin PEKPELVAN

Özet

Osmanlı hâkimiyeti döneminde Manisa Şehri, Osmanlı şehzadelerinin dil, sanat ve devlet yönetimi gibi konularda eğitim gördükleri üretim, ticaret, kültür ve sanat merkezlerinden birisiydi. Manisa'da camiler, medreseler, imaretler, çarşı, hamam gibi pek çok mimari eser yaptıran padişahlar ve saray ileri gelenleri, aynı zamanda bu camilere sanat değeri yüksek olan Mushaf-1 Şerîf'ler de vakfetmişlerdir. Bu Mushaf-1 Şerîf'ler den pek çoğu bugün, Manisa Yazma Eserler Kütüphanesi Müdürlüğ̈̈'nde korunmaktadır. Kütüphane'de XIV-XX. yüzyıllar arasına tarihlendirilen 53 adet Mushaf-1 Şerîf bulunmaktadır. Kur'an-1 Kerîm'e verilen önemin gösterilmesi açısından, hattatlar en güzel yazılarını bu kutsal kitap için yazmışlar, müzehhibler zahriye, serlevha ve hâtime sayfaları ile sûre ve cüz başlarını, gülleri ve noktaları motiflerle özenle bezemişler, mücellidler de yaptıkları ciltlerde bütün hünerlerini sergilemişlerdir.

Bu makalede, Manisa Yazma Eserler Kütüphanesi Müdürlüğü'nde bulunan dört adet Mushaf-1 Şerîf, hazırlandıkları dönemlerin tezhip özelliklerini yansıtmaları açısından örnek olarak seçilmiş, Mushaf-1 Şerîf'lerin bezemeli bölümleri hakkında kısa bilgiler verildikten sonra, serlevha bezemeleri motif, renk ve desen açısından incelenmiştir.

Anahtar Kelimeler: Yazma, Mushaf-1 Şerîf, Serlevha, Tezhip, Bezeme

\section{Samples From Heading Ornaments of Mushaf-1 Şerîf (The Korans) In The Manuscripts Library Of Manisa}

\begin{abstract}
The Manisa City was one of production, commerce, culture and art centers where the Ottoman Sultans' sons had been educated in the areas of language, art and state management during Rule of the Ottoman. Sultans
\end{abstract}

\footnotetext{
'Yrd Doç., Celal Bayar Üniversitesi Turgutlu Meslek Yüksekokulu El Sanatları Bölümü, bpekpelvan@hotmail.com
} 
and notables of the palace who had many architectural works such as mosques, madrassas, aims houses, bazaars, baths made, in the same time, had devoted the Korans with high artistic value to these mosques. Today, many of such Korans are preserved in the Manuscripts Library Directorate of Manisa. Three each of 53 Korans in the library which had been dated to the XIV-XXth centuries had been bound as fascicles. In this article, four Korans in the Manuscripts Library Directorate of Manisa are selected as samples. The calligraphers had written their best calligraphies on the Korans, the illuminators had decorated introduction, heading and epilogue pages carefully with motifs, the bookbinders had showed their proficiency on the binds in terms of indicating importance of the Quran.

In terms of reflecting the illumination features of the periods and examined heading ornaments of the Korans from the points of motifs, colour and design.

Key Words: Manuscript, the Koran, Heading, Illumination, Ornament

\section{Giriş}

T.C. Kültür ve Turizm Bakanlığı Türkiye Yazma Eserler Kurumu'na bağlı olarak açılan "Manisa Yazma Eserler Kütüphanesi Müdürlüğü" 2011 yılında kurulmuştur. 1945 yılından 2011 yılına kadar Manisa İl Halk Kütüphanesi "Yazma Eserler Bölümü"nde korunan eserler, bu tarihten itibaren Manisa Yazma Eserler Kütüphanesi Müdürlüğü sorumluluğuna verilmiştir. Manisa İl Halk Kütüphanesi'ne Manisa Muradiye ve Çeşnigir Kütüphaneleri'nden ve çeşitli vakıf koleksiyonlarından getirilen bu eserlerin, Kütüphane arşiv kayıtlarına göre, şahıslar tarafından da bağışlandığı anlaşılmaktadır (Karagöz,1974:67-68). Kütüphane Müdürlüğ̈̈'nde 8050 adet yazma eser bulunmaktadır. Dinî, edebî ve bilimsel başlıkları altında toplanan yazma eserlerin 53 adedi Mushaf-1 Şerîf olup, 3 adedi cüzler halinde cildlenmiştir.

Müzehheb yazma Mushaf-1 Şerîflerin zahriye, serlevha ve hâtime sayfaları, sûre ve cüz başlıkları, gülleri ve durakları döneminin en güzel motifleriyle bezenmiştir. ${ }^{1}$ Zahriyeden sonra gelen ve metnin başladığı bölüm serlevhadır. Mutlaka karşılıklı çift sayfa halinde düzenlenen

${ }^{1}$ Çiçek Derman, Mushaf-1 Şerîf'lerde yer alan tezhipli bölümleri, makalesinde ayrıntılı biçimde açıklamıştır. Bkz. Derman,1999:108-109 
(Derman,1999;109) serlevhalara dibace veya mihrâbiye adı da verilir (Aksu,1999:132). Mushaf-ı Şerîf'lerde serlevhaların yazı alanı genellikle, kare, dikdörtgen, daire veya oval biçimde ve dilimli veya düz bir şekilde tasarlanmıştır. Sağ sayfaya Fatiha Sûresi'nin tamamı, karşı sayfaya ise, Bakara Sûresi'nin ilk âyetleri yazılmıştır. Sûre isimlerinin, nerede nazil olduklarının ve âyet sayılarının yazılı olduğu bölümler de yazı alanıyla uyum içerisinde olacak tarzda düzenlenmiştir.

\section{Mushaf-1 Şerîf'lerin Serlevha Bezemelerinden Örnekler}

\section{MHK 931 Envanter Numaralı Mushaf-1 Şerîf:}

Ketebe kaydı bulunmayan Mushaf-ı Şerîf 451 varaktan oluşmaktadır. Cildi vişneçürüğü renkli deri ile kaplıdır. Bezemeli alanları mülemma yekpare şemse tarzında bir işçilik gösterir. Sırt kısmındaki kitâbede sülüs yazı cinsi kullanılarak satır istifi nizamında, Vâkıa Sûresi'nin 77-80. âyetleri yazılıdır. ${ }^{2}$ (Resim 1a) Mushaf-1 Şerîf'in cild ölçüsü: 310x217 mm. ve yazılı alan ölçüsü: 247x157 mm. olup, saykallı âbâdî kâğ $t^{3}$ üzerine 11 satır olarak düzenlenmiştir. Sûre başlıklarında altın sıvama zemin üzerinde yer alan yazılar, sülüs yazıdır. Metinler ise, iki farklı kalem ve nesih yazı ile yazılmıştır. Kalın nesihler orijinal metin, ince nesihler Osmanlı Türkçesi ile yazılmış olan meâllerdir. ${ }^{4}$ Hâtime sayfasında (451 a); Halid Paşa'nın ${ }^{5}$ Kızıl Murat Köyü Camiine vakfettiğine, kitabın hediye edilmemesi ve satılmamasına dair bir kayıt bulunmaktadır. Zahriyesi, sûre başları, gülleri ve durakları bezemelidir.

\footnotetext{
2 “İnnehu le kur-ânun kerîm (un)” Şüphesiz bu, değerli bir Kur'an'dır, "Fî kitâbin meknûn (in)" Korunmuş bir kitaptır. "Lâ yemessuhû illâ-lmutahherûn (e)" Ona ancak temizlenenler dokunabilir. "Tenzîlun min rabbi-l'âlemîn (e)" O, âlemlerin Rabbinden indirilmiştir.

${ }^{3}$ Âbâdî kâğıt: Hindistan'da Devlet-âbât şehrinde yapıldığı için bu ismi almıştır. Dut ağacı elyafindan hazırlanan kâğıtlar parlak ve sarımtrak renklidir. (Özen,1985:1)

4 Makalemizde incelediğimiz Mushaf-1 Şerîf'lerin hat sanatına dair değerlendirmeleri, SA.Ü. İlâhiyat Fakültesi Öğretim Üyesi Yrd. Doç. Dr. Mehmet Memiş ve Güzel Sanatlar Fakültesi Öğretim Görevlisi Orhan Altuğ tarafindan yapılmıştır.

${ }^{5}$ Manisa'nın ileri gelen eşrafindan olan Halid Paşa, Karaosmanoğlu ailesinden olup, mülkiye paşalarındandır. Kurtuluş Savaşı'nda Yunan askerlerine karşı savaşmış ve şehit olmuştur. Halid Paşa'nın yaşamış olduğu Papazlı ve daha sonra Hocalı adı verilen Kasaba, Cumhuriyetin ilânından sonra Halidpaşa adını almıştır. (Uluçay,1946:58-59; Su,1982:35)
} 
Zahriye (v.1b-2a) karşılıklı iki sayfa olarak düzenlenmiştir. Desen dikdörtgen alanda $1 / 4$ simetrik olup, hatâyî ve rûmî motiflerinden oluşan bir kompozisyona sahiptir. Altın rûmî ipliklerin sınırlandırdığı lâcivert renkli ve altın zeminli paftalar, merkezde ve köşebentlerde $1 / 4$, dikey eksende $1 / 2$ simetrik desenlidir. Lâcivert cedvellerin arasında kalan kitâbeli zencirekte, ters simetrili bir desen görülmektedir. Dış pervazda (Derman,2002:192), sade altın rûmî ipliklerin ayırdığı lâcivert zeminli paftalar ve bunların dışında kalan alanlarda, çok ince işçilikle yapılmış zer-ender-zer ${ }^{6}$ bir bezeme görülür. Dış pervaz dendanlı lâcivert iplikle sonlandırılmış olup, üzerine yine lâcivert renkle tığlar yapılmıştır. (Resim 1b)

Zahriye ile desen ve renk açısından uyum içerisinde olduğu görülen serlevha da (v. 2b-3a), karşıllklı iki sayfa halinde düzenlenmiştir. Serlevha bezemeleri düz levha (Derman,2009:531) tarzındadır. (Resim 1c) Fatihâ Sûresi'nin âyetleri ile Bakara Sûresi'nin ilk âyetlerinin yer aldığı 110x105 $\mathrm{mm}$. boyutlarındaki kareye yakın yazı alanının her iki yanına, ince uzun koltuklar (Tanındı,1999:120) yapılmıştır. Koltuklara ikişer adet kitâbeli pafta yerleştirilmiş ve içleri sade hatâyî gurubu (Birol-Derman,1991:65) motiflerden oluşan $1 / 2$ ters simetrili bir desenle bezenmiştir.

Duraklar, sıvama altın zeminli şeşhaneli durak örneğidir. Serlevhaların sûre başlıklarında ve sûre âyetlerinin yazılı bulunduğu bölümlerin alt kısmında yer alan, sûre başlığ görünümünde düzenlenmiş olan yatay dikdörtgen bölümlerin içine, rûmî ve hatâyî gurubu motiflerden oluşan $1 / 4$ simetrik bir desen yapılmıştır. Sûre başlıklarının ortasına açılan kitâbeye, sülüs yazı cinsi kullanılarak, altın zemin üzerine yine altınla yazılar yazılmıştır.7 Kitâbenin dışında kalan kısımda, altın iplik üzerine yerleştirilen sade rûmî motifler ile hatâyî gurubu dalları arasında lacivert zeminli alanlar oluşturulmuştur. Rûmî motiflerinin üzerinde yer aldığ 1 iplikler ile hatâyî grubu dalların birleşerek oluşturduğu kapalı formların içine mat altın sürülmüş ve rûmîler parlatılmıştır. Paftalı alanlara rûmî ve hatâyî gurubu motiflerden meydana gelen bir desen işlenmiştir. Yazı alanının altında yer alan sûre başlığı görünümündeki yatay dikdörtgen

6 Zer-ender-zer: Sarı altın üzerine yeşil altınla yapılan bezemedir. (Özönder,2003:221) Tek renk altın kullanılarak, altının parlatılması ve mat bırakılması yoluyla yapılan bezeme tekniğine de bu isim verilmektedir.

7 Serlevhanın 2b sayfasında; üstte "Sûretü'l-Fâtihatü'l-Kitâb", altta "Vahy-i Seba Âyetin", 3a sayfasında; üstte "Suretü'l-Bakara Mietâni”, altta "Ve Semânûn Ve Sitte Âyetin" yazmaktadır. 
bölümlerin içine de aynı tarz bezemenin yapıldığı görülmektedir. Bütün bu yazı ve bezeme alanlarını üç taraftan, enli ve kenarları düz bir dış pervaz çevrelemektedir. Dış pervaz, sarı altın iplikler üzerine yerleştirilen sade rûmî motifleriyle paftalandırılmıştır. Esas zemin sarı altın, rûmî ipliklerin paftaladığ 1 alanlar ise, lâcivert ve siyah renklidir. Her iki zeminde rûmî ve hatâyî gurubu motiflerin oluşturduğu $1 / 2$ simetrik bir desen görülmektedir. Serlevha bezemelerinin üzerinde yer aldığı kompozisyon bölümleri, iki ince altınlı cedvel arasına daha kalın olan lâcivert bir cedvel ile sınırlandırılmıştır. En dış kısımda, lâcivert cedvel üzerine yerleştirilen tı̆̆ çıkışları ile desenin sayfa kenarına doğru yumuşatıldığı görülmektedir.

Değerlendirme: Mushaf-1 Şerîf'in nemden etkilendiği bariz bir şekilde görülmektedir. Bu nedenle, bazı desenlerin belirginliği kaybolmuş ve yıpranan bazı sayfaları da restore edilmiştir. Hâtime sayfası bezemesizdir. Mushaf-1 Şerîf'in bezemelerinde ince bir işçilik hâkimdir. Serlevhalarda kuzu yerine lâcivert bir cetvel üzerinde yer alan tığlar, Müzehhib Bayram b. Derviş Şî̀'in ${ }^{8}$ hazırladığı bildirilen 1523-24 tarihli TSM E.H. 58 de bulunan Mushaf-1 Şerîf'in zahriyesinin (Tanınd1,2003:866-867) tığlarıyla birebir aynıdır. Sözü edilen her iki Mushaf-1 Şerîf'in tezhiplerindeki kompozisyon bölümlerinin düzenlenişi, bu bölümlerin lâcivert cedvellerle çevrelenişi, rûmî ve bazı hatâyî motiflerinin çizim stilleri ve bezemede zer-ender-zer tekniğinin kullanılmış olması açılarından yaklaşıldığında, incelediğimiz Mushaf'ı Şerîf de XVI. yüzyıla tarihlendirilebilir.

Deri ile kaplanmış cildin deffeleri, sertâbı ve miklebinin üzerine yerleştirilmiş olan paftalar kitâbeli zencirek olarak düzenlenmiş olup, altın zeminler üzerinde hatâyî gurubu motiflerden oluşan $1 / 2$ ters simetrik kompozisyon uygulanmıştır. Paftalar birbirinden oldukça ayrıdır. Ortada bulunan altın varak zeminli ve bezemeli geniş dikdörtgen bölüm, birisi kitâbeli zencirek olan kalın üç bordürle çevrelenmiştir. Orta alanda hatâŷ̂ gurubu motiflerden oluşan bir desen görülmektedir. Desen, " $S$ " ve " $C$ " hareketlerinden oluşan ipliklerle paftalara ayrılmıştır. Cildin motifleri ve desen zeminleri altınla kaplıdır. MHK 931 Nolu Mushaf-1 Şerîf'in cildi ile

8 "Bayram Derviş" ismi, 965-66 tarihli olan ehlihiref defterlerinde "Cemaatı Rûm Nakkaşları” başlığı altında sıralanmış olan nakkaşlar arasında geçmektedir. Baba adının "Derviş Şir" olduğu müzehhibin kendi imzası içinde mevcuttur. Kanuni devrinin bir müzehhibi olduğu, saray nakkaşhanesinde çalıştığı ve başında Kara Memi Çelebi’nin bulunduğu defter kayıtlarında yer almaktadır. (www. turkislamsanatlari.com) 
Uşak Üniversitesi Sosyal Bilimler Dergisi

$2013,6 / 3$

\section{B. PEKPELVAN}

Şah Tahmasp tarafından II. Selim'e (1566-1574) hediye edilen Mushaf-1 Şerîf'in cildi (Tanındı,1999:105) arasında, paftaların düzenlenişi, kitâbeli zencireğin ve ortada geniş bir dikdörtgen alanın kullanılması, paftaların zemin ve motiflerinin sıvama altınla kaplanması açılarından benzerlikler bulunmaktadır. Bütün bu bilgilerden yola çıkıldığında, Mushaf-1 Şerîf'in cildinin de XVI. yüzyıla ait olduğu söylenebilir. (Resim 1a) ...

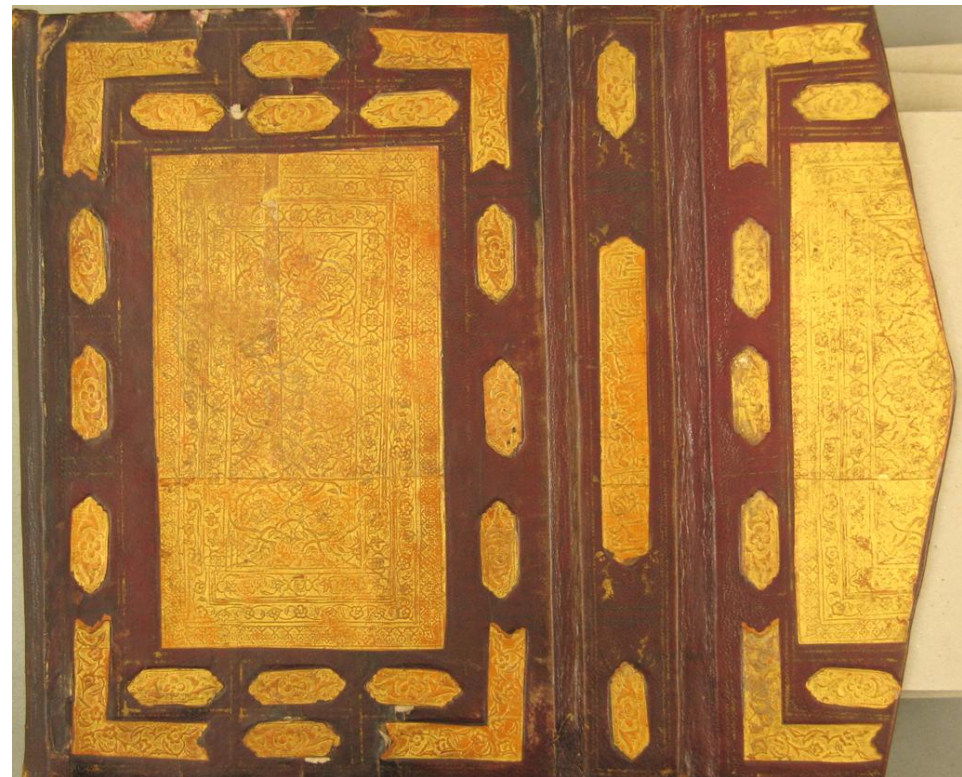

Resim 1a: MHK 931 Envanter Numaralı Mushaf-1 Şerîf' in Cildi (45 Hk 931_0000_cilt-1) 


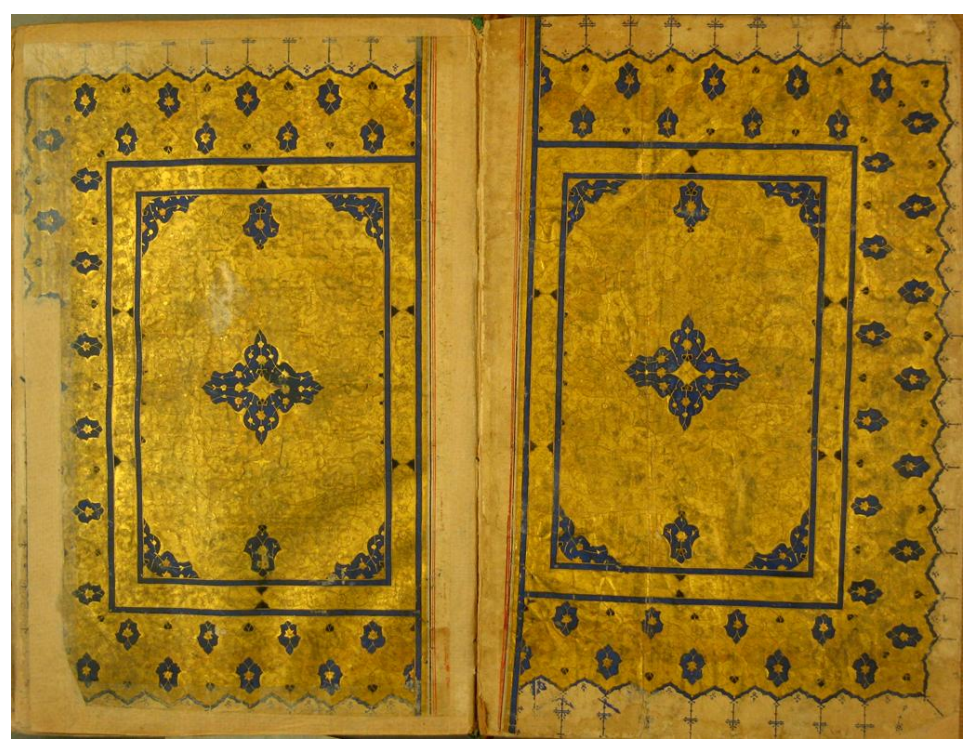

Resim 1b: MHK 931 Envanter Numaralı Mushaf-ı Şerîf'in Zahriyesi (v.1b-2a), (45 Hk 931_0001)

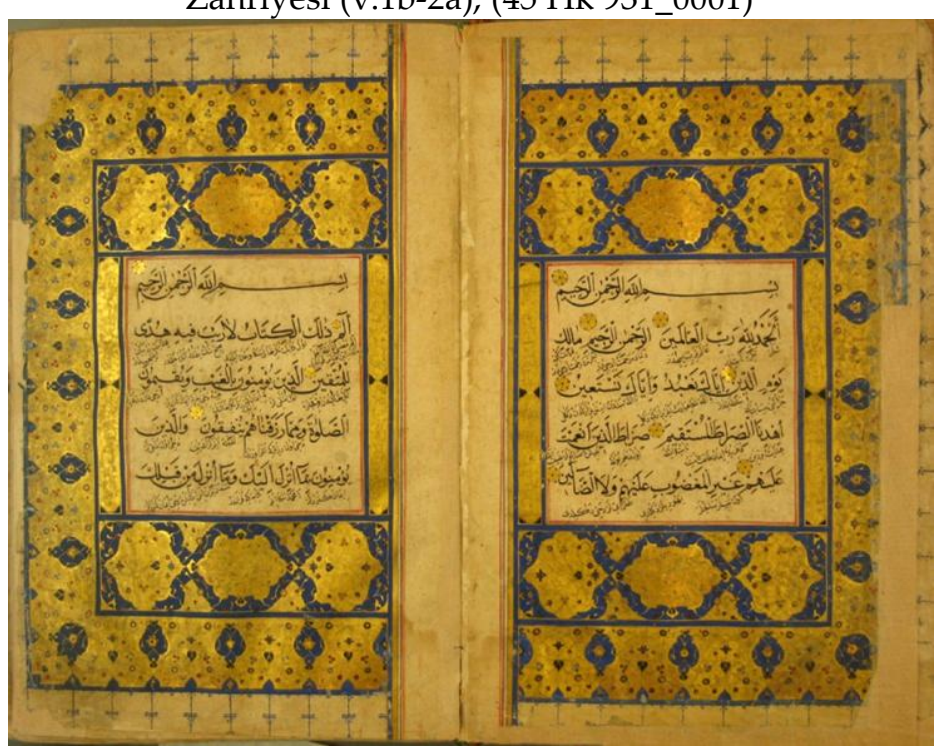

Resim 1c: MHK 931 Envanter Numaralı Mushaf-ı Şerîf'in Serlevhası (v. 2b-3a), (45 Hk 931_0002) 


\section{MHK 9420 Envanter Numaralı Mushaf-1 Şerîf:}

Ketebe kaydı ve hattat adı bulunmayan Mushaf-1 Şerîf, 401 varaktan oluşmaktadır. Miklebli olan cildi, bordo renkli deri ile kaplı olup alttan ayırma şemse tarzında düzenlenmiştir. ${ }^{9}$ (Resim 2a) Mushaf-1 Şerîf' in cild ölçüsü: 452×335 mm. ve yazılı alan ölçüsü:278x180 mm dir. Saykallı âbâdî kâğıt üzerine 11 satır halinde yazılmıştır. Yazı karakteri reyhani gibi görünse de ince kalemle yazılmış bir muhakkak yazı örneğidir. Bunun için en önemli gerekçe, reyhani yazının elif'lerinde zülfe olmadı̆̆ı, buradaki yazı karakterinde ise, muhakkak yazıda görülen zülfelerin bulunmasıdır. Bir başka ayrıntı da, harekelerde yazının kalem farklılığıdır. Harekelerin kalemi incedir. Bu nedenle, yazı karakterinin muhakkak olduğunu belirtmek isabetli olacaktır. Kütüphane demirbaş kaydına göre, Manisa Arkeoloji Müzesi'nden Kütüphane'ye getirilmiş olan Mushaf-1 Şerîf'de zahriye ve hâtime sayfası bulunmamaktadır. Serlevha, sûre başlıkları ve duraklar klâsik dönem bezeme karakterlidir. Eserde gül yerine, sayfa kenarlarına ve sûre âyetleri yanına lâl mürekkebi ve altınla yazıların yazıldığı görülmektedir.

Serlevha (v.1b-2a) karşılıklı iki sayfa halinde hazırlanmış ve düz levha tarzında düzenlenmiştir. (Resim 2b) Yazı aralarına, zeminleri boş bırakılmış olan altın tahrirli beyne's-sütûr yapılmıştır. Duraklar sıvama altın zeminli helezonik durak örneğidir. Serlevhanın sûre âyetleri, $153 \times 147 \mathrm{~mm}$. boyutlarında kareye yakın alanlar içerisine yazılmıştır. Bu alanların her iki yanında yer alan ince uzun koltuklar içine ikişer adet kitâbeli pafta yerleştirilmiştir. Paftaların içi, lâcivert zemin üzerine sade hatâyî ve gonca motiflerinden oluşan $1 / 2$ ters simetrili bir bezeme ile doldurulmuştur. Serlevhanın sûre başlıkları ve yazı alanının altında yer alan sûre başlığı görünümündeki yatay dikdörtgen bölümler, altın rûmî ipliklerle altın ve lâcivert zeminli paftalara ayrılmıştır. Başlıkların ve yatay dikdörtgen bölümlerin etrafını yă̆ yeşili cedveller çevirmektedir. Ortada bulunan iç kitâbelerin altın zeminleri üzerine, sülüs yazı cinsi kullanılarak üstübeçle sûre isimleri, nerede nazil oldukları ve âyet sayıları yazılmıştır. Kitâbe dışında kalan bölüm, rûmî ve hatâyî gurubu motiflerinden oluşan 1/4 simetrik desenlidir. Sarılma (pîçîde) rûmilerin oluşturduğu paftaların zeminleri mat bırakılmış, rûmîler parlatılmıştır.

\footnotetext{
${ }^{9}$ MHK 9420 ve 3158 Envanter numaralı Mushaf-1 Şerîf'lerin ciltleri Gül Güney tarafından ayrıntılı olarak incelenmiş ve Mushaf'1 Şerîf'ler hakkında kısa bilgi verilmiştir. (Güney,2010: 565-566)
} 
Bütün yazı ve bezeme alanlarını üç taraftan, altın ve lacivert zeminli, kenarları dendanlı bir dış pervaz çevrelemektedir. Bu bölümün bezeme tarzı, sûre başlıkları ve yazı alanının altında yer alan dikdörtgen bölümlerle aynıdır. Rûmîlerin oluşturduğu zer-ender-zer tekniğinde yapılmış paftalar, lâcivert renkli zemin üzerine altın rûmi ipliklerle arada pafta görünümleri oluşturacak tarzda yerleştirilmiştir. Yeşil, kırmızı ve eflâtun renkli hatâyî gurubu motifler bezeme alanlarını doldurmaktadır. Dendanlı dış pervazın kenarı altın bir iplikle çevrelenmiştir. Yoğun bir bezemeye sahip olan dış pervaz, sade çift tahrir çiçek görünümlü lâcivert tığlarla sona ermektedir.

Değerlendirme: Mushaf-1 Şerîf'in nemden etkilendiği ve bu nedenle, bazı desenlerin belirginliğinin kaybolduğu görülmektedir. Yatay dikdörtgen şeklinde düzenlenen sûre başlığı bezemelerindeki motifler sıvama altınlı ve tahrirsiz olup, âherli kâğıt üzerine işlenmişlerdir. Sûre başlığı bezemeleri tamamlanmamış izlenimi vermektedir. Serlevhalarda, lâcivert renk ile altın oranının uyumlu olması, renklerin parlak kullanılması ve bezemelerinin ince bir iş̧̧ilik göstermesi açısından değerlendirildiğinde, Mushaf-1 Şerîf XVI. yüzyıl yazma eserleri arasında tarihlendirilebilir.

Mushaf-1 Şerîf'in cildinin deffelerinin ortasında, alttan ayırma şemse (Özen,1998:15) tarzında çalışılmış beyzî, dilimli ve salbekli birer şemse ve köşelerde köşebendler yer almaktadır. (Resim 2a) İçlerine serbest kompozisyonlu saz yolu motifleri işlenmiştir. Aynı kompozisyon şeması ve bezeme tarzı miklebde de görülmektedir. Motiflerin üzerinde yer aldığı zemin altınlıdır. Motifler deri renginde bırakılmıştır. Gömme olarak hazırlanan bezemeli bölümlerin etrafını altın cedveller sınırlamaktadır. XVI. yüzyılın ilk yarısından itibaren, dilimli şemse ve köşebend içlerinin saz üslûbunda yapılmış bir yaprak kümesinden veya birkaç saptan çıan hatâŷ̂ gurubu motiflerle doldurulduğu görülmektedir (Tanındı,1999:104). Aynı teknik ve tarzda yapılmış bezemeler, XVI. yüzyıla tarihlendirdiğimiz MHK 9424 Envanter numaralı Mushaf-ı Şerîf' in cildinde de bulunmaktadır. Sonuç olarak, 9420 Envanter numaralı Mushaf-1 Şerîf'in cildinin de XVI. yüzyıla ait olduğu söylenebilir. 


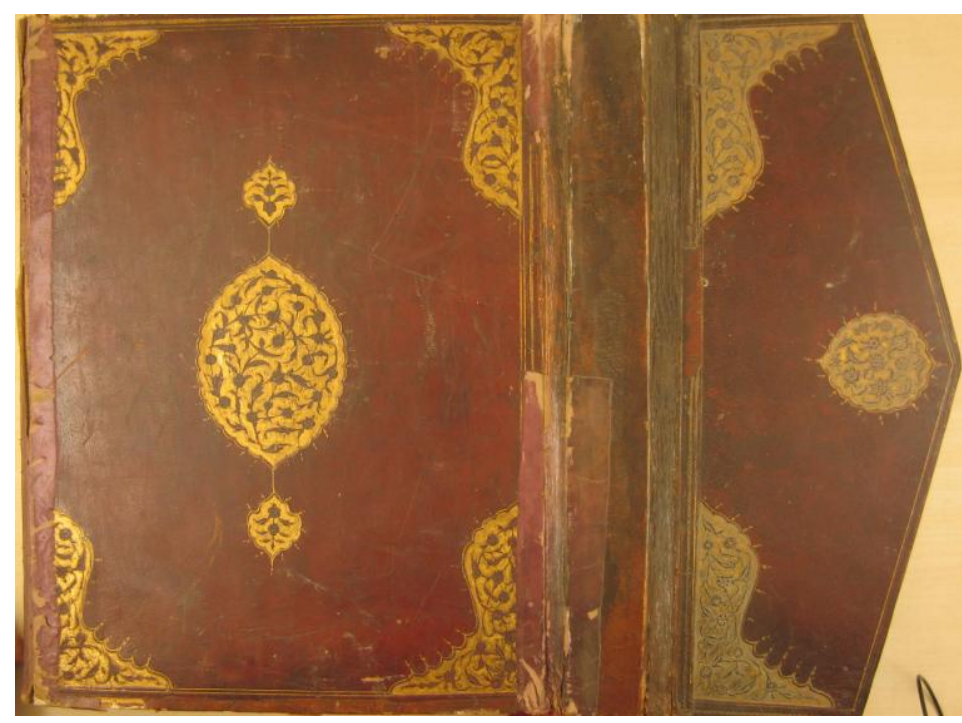

Resim 2a: MHK 9420 Envanter Numaralı Mushaf-1 Şerîf'in Cildi (45 Hk 9420_0000_cilt-2)

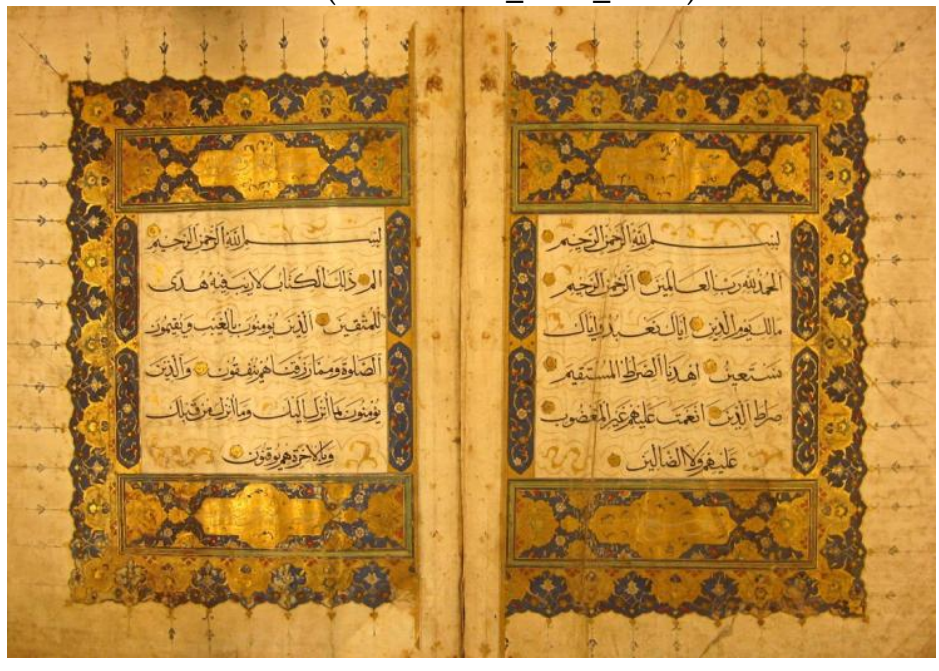

Fotoğraf 2b: MHK 9420 Envanter Numaralı Mushaf-1 Şerîf'in Serlevhasi (v.1b-2a), (45 Hk 9420_0002)

MHK 3158 Envanter Numaralı Mushaf-ı Şerîf: 
Ketebe kaydı 1219/1804 olan Mushaf-1 Şerîf, 310 varaktan oluşmaktadır. Miklebli olan cildi fes rengi deri ile kaplı olup, mülevven yazma cilt olarak hazırlanmıştır. Cildin deffelerinin ortasında yer alan salbekli şemse ve köşebentler, iri rûmi motiflerinden oluşan bir desene sahiptir. Altın sıvama rumîler teberle, desen aralarına serpiştirilen altın noktalar ve zencirekli bordür, yekşah demiriyle süslenmiştir. Deffelerde uygulanan desen miklebde de devam ettirilmiştir. (Resim 3a) Mushaf-1 Şerîf'in cild ölçüsü: 165x115 mm. ve yazılı alan ölçüsü: 100x55 mm. dir. Saykallı âbâdî kâğıt üzerine harekeli nesih hattı ile 15 satır halinde yazılmıştır. Mushaf-ı Şerîf'in hâtime sayfasında, hattatının Hilmi adıyla bilinen Muhammed el-Maruf olduğu belirtilmektedir. Cildin iç yüzünde Muradiye Kütüphanesi'nden getirildiğine ilişkin bir mühür vardır. Mushaf-1 Şerîf'de zahriye bulunmamaktadır. Serlevha, sûre başlıkları ve duraklar bezemelidir.

Serlevha (1b-2a) karşılıklı iki sayfa halinde hazırlanmış olup, düz levha tarzında düzenlenmiştir. Klâsik dönem bezeme özelliği olan zerender-zer işçiliğine sahiptir. (Resim 3b) Sûre âyetlerinin yazılı olduğu alan $45 \times 47 \mathrm{~mm}$. boyutlarındadır. Sekizgen yıldız formu şeklinde, kenarları içe ve dışa bakan yaylarla ve kırık çizgilerle hareketlendirilmiştir. ${ }^{10}$ Duraklar, devrin özelliğini yansıtan, sıvama altın zeminli ve renkli müzehhep durak örneğidir. Yazı alanı bezemeleri $1 / 4$ simetrik, serlevhanın sûre başlıkları ve yazı alanının altında yer alan sûre başlığı görünümündeki yatay dikdörtgen bölümlerin bezemeleri $1 / 2$ ters simetrik, diş pervazda bulunan lâcivert ve altın zeminli paftaların her birisi $1 / 2$ simetrik desenlidir. Desenin rûmî ve hatâyî gurubu motiflerden oluştuğu görülmektedir. Zemin altını parlatılmış, motifler ise mat bırakılmıştır. Serlevhadaki bütün rûmîlerin iç bünyeleri ile hatâyî gurubu motifler kırmızı ile renklendirilmiştir.

Serlevhada, sûre başlıklarına ve yazı alanının altında yer alan sûre başlığı görünümündeki yatay dikdörtgen bölümlerin ortasına, zemini altınlı

\footnotetext{
${ }^{10}$ Mushaf-1 Şerîf'in Fatiha Sûresi'nin içinde yer aldığı pafta biçimini, H. 1220 tarihli, Muhammed el- Üsküdarî tarafindan tezhiplenmiş Delâilü’l- Hayrât adlı eserin tezhipli başlık sayfasında da görebiliriz. (Ülker,1997:128) XVIII. yüzyılın ilk çeyreğinden itibaren Osmanlı sanatına giren Batı sanatı etkisi, aynı yüzyılın ortalarında ağırlığını daha fazla hissettirir. XIX. yüzyılın sonuna kadar etkin olan Barok-Rokoko adı verilen üslûp, Osmanlı sanatının hemen hemen her sanat alanında hâkim olur. Bu üslûpta iç ve dış bükey çizgilerin yan yana getirilmesi, $\mathrm{S}$ ve C kıvrım dalların kullanılması ile oldukça hareketli yüzeyler elde edilmiştir. Bkz. (Arseven, t.y.: 230; Duran,1999:127; İrez,1990:25, 27)
} 
kitâbeler üzerine, sülüs yazı cinsi kullanılarak üstübeçle sûre isimleri, nerede nazil oldukları ve âyet sayıları yazılmıştır. Başlıkların ve sûre âyetleri dışında kalan bölümlerin bezemeleri motif ve kullanılan teknik açısından aynıdır. Sûre başlıklarını ve yatay dikdörtgen bölümleri mat altın sürülmüş bir cedvel ile lâcivert renkli boya sürülmüş bir iplik (Derman,2002:192) çevrelemektedir. XIX. yüzyıl tezhiplerinde görüldügü̈ üzere, gölgeli olarak kırmızıya boyanmış, üzerine koyu kırmızı renk ile kafes çizgileri çekilmiş ve aralarına altın sürülmüş daireler serpiştirilmiş olan iç pervaz, bütün bu yazı ve desen alanlarının çevresini dolanmaktadır. Zeminlerine sırasıyla lâcivert renk ve altın sürülmüş olan dendanlı paftalar, $\mathrm{d}_{1 s ̧}$ pervazları oluşturmaktadır. Paftaları beyaz renkli bir iplik ve altın çevrelemektedir. Paftaların içindeki desenler rûmî ve hatâyî gurubundan olup, birbirinden bağımsızdır. Serlevha deseni, dönemin karakteristik özelliği olan lâcivert ve kırmızı renkli serbest vuruşlu sade tığlarla sona ermektedir. ${ }^{11}$

Değerlendirme: Mushaf-1 Şerîf'in cildinin nemden etkilendiği ve derinin bazı kısımlarında rengin değiştiği görülmektedir. Cildin yıpranan bölümleri üzerine, cildin renkli fotokopisi çekilerek yapıştırılmıştır. (Resim 3a) Yine aynı şekilde, 309 b ve 310 a sayfaları kenarına, serlevhadan çekilen renkli fotokopiler eklenmiştir. Mushaf-1 Şerîf'in bezeme motifleri Osmanlı klâsik dönem tezhibine göre, irileşmiş ve seyrelmiştir. Bazı durak ve güllerin desenlerinin tezyini bir kurala uygun yapılmadığ 1 görülmektedir. Desende paftaların yana doğru şişkinleşmiş yapıları dönem özelliği olarak karşımıza çıkmaktadır. Osmanlı klâsik dönem tezhip sanatında kullanılan lâcivert renk soluklaşmış, altın daha geniş alanlara uygulanarak boya ve altın dengesi bozulmuştur.

\footnotetext{
${ }^{11}$ XVII. yüzyılın yarısından itibaren tığ biçimleriyle birlikte renklerde de değişim olmuş, tığlarda lâciverdin yanı sıra kırmızı renk de kullanılmaya başlanmıştır. (Akbaş ve diğerleri,1991:X)
} 
Uşak Üniversitesi Sosyal Bilimler Dergisi

$2013,6 / 3$

\section{B. PEKPELVAN}

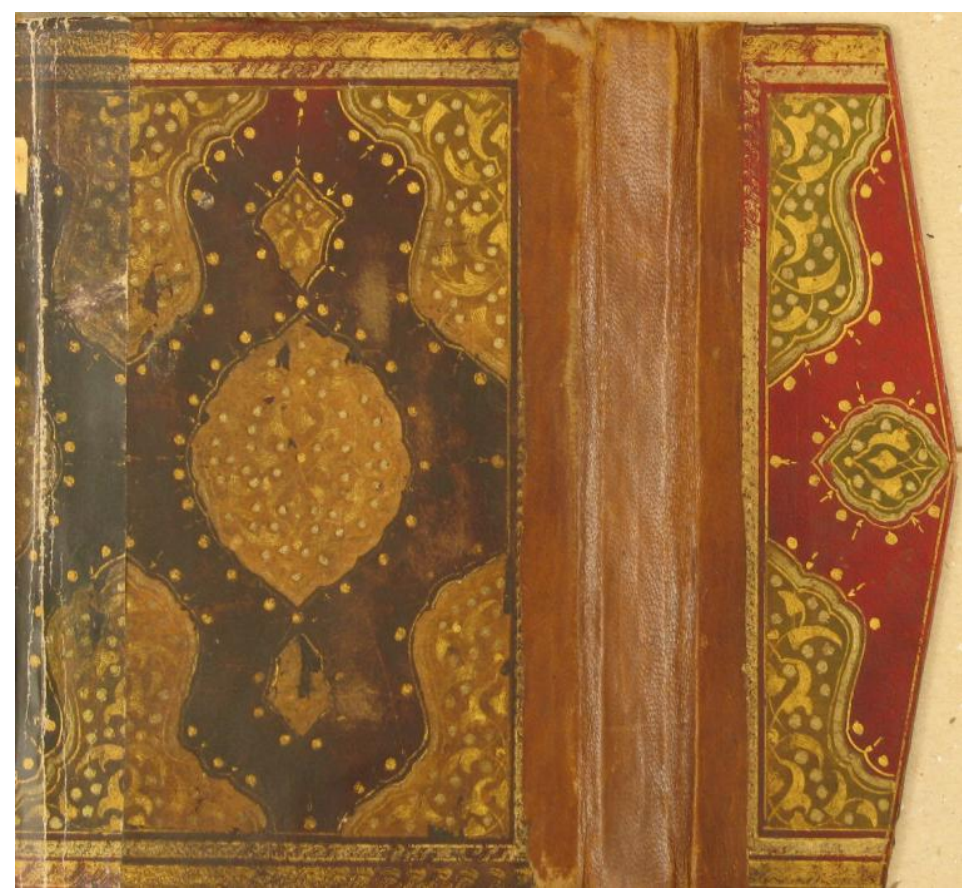

Resim 3a: MHK 3158 Envanter Numaralı Mushaf-1 Şerîf'in Cildi (45 Hk 3158_0000_cilt-2)

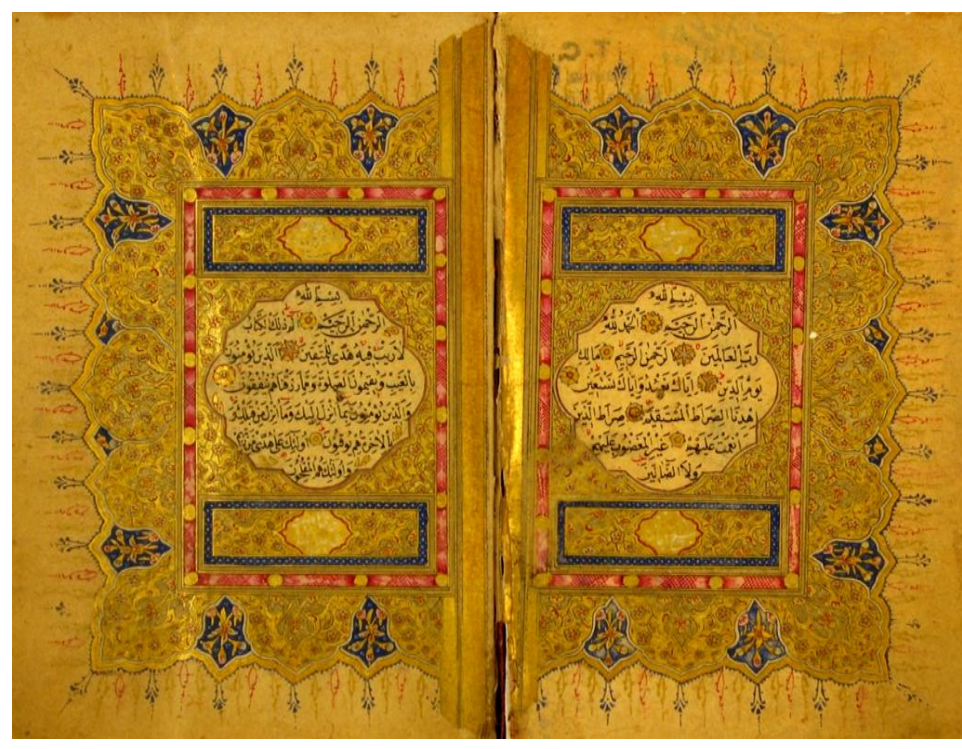

Resim 3b: MHK 3158 Envanter Numaralı Mushaf-1 Şerîf'in 
Serlevhası (1b-2a), (45 Hk 3158_0002)

\section{MHK 574 Envanter Numaralı Mushaf-ı Şerîf:}

Ketebe kayd1 1248/1831 olan Mushaf-1 Şerîf, 303 varaktan oluşmaktadır. Miklebli olan cildi, vişne çürügü̈ renkli bir deri ile kaplanmıştır. Mülemma şemse tarzında çalışılan cildin deffelerinin ortasına beyzî, dilimli ve salbekli birer şemse ve köşelere de köşebendler yerleştirilmiştir. Bunların içleri, bitkisel desenlerle doldurulmuş ve bu alanların tümü diştan zencirekle çevrelenmiştir. Salbekler şemseden oldukça ayrıdır. Mushaf-1 Şerîf'in cild ölçüsü:145x90 mm. ve yazı alanı ölçüsü:90x45 mm. dir. Nesih hat ile yazılmış olup, satır sayısı 15 dir. Zahriyesi bulunmayan Mushaf-1 Şerîf'in, serlevhası, gülleri, durakları ve hâtime sayfası bezemelidir.

Karşılıklı iki sayfa halinde hazırlanmış olan serlevha (1b-2a) iklil serlevha (Derman,1999:109) tarzında düzenlenmiştir. (Resim 4) Âyet satırları arasına sıvama altınla beyne's-sütûr yapılmıştır. Duraklar devrin özelliğini yansıtan sıvama altın zeminli durak örneği olup, kaba bir iş̧̧ilik sergilemektedir. Sûre âyetlerinin bulunduğu dikdörtgen alan 40x35 mm. boyutlarındadır. Bunun her iki yanında yer alan ince uzun koltuklar altın zeminli saç örgüsü olarak çalışılmış olup, etrafını kırmızı renkli zemin üzerine beyaz renkle "+" biçimi koyulmuş bir iplik çevrelemektedir. Serlevhanın sûre başlıklarında ve yazı alanının altında yer alan sûre başlığı görünümündeki yatay dikdörtgen bölümlerin ortasına, zeminine altın sürülmüş birer iç kitâbe yerleştirilmiştir. Üzerlerine hatt-1 icâze yazı cinsi kullanılarak üstübeçle sûre isimleri, nerede nazil oldukları ve âyet sayıları yazılmıştır. Başlıkların ve yatay dikdörtgen bölümlerin etrafını açık mavi ve kavunçi renkte iplikler çevrelemektedir. Üzerlerine dönemin kalem işlerinde görülen renkli dalgalı hareketler, kırmızı ve lâcivert noktalar işlenmiştir. Başlığın üst bölümü üç taraftan, sarı renkli ve kırmızı noktalı bir iplikle sınırlandırılmış olup, kırmızı, lâcivert ve altın zeminler üzerine iri rûmî ve hatâyî gurubu motiflerden oluşan bezeme yapılmıştır. Zemin iğne perdahı ve beyaz noktalarla hareketlendirilmiştir. Ulama karakterli desen, dendanlı kırmızı, mavi ve beyaz renkli ipliklerle sonlandırılmıştır. Tığlar, kırmızı ve lâcivert renkli olup, bitki görünümlüdür. Bütün bu alanları üç taraftan, 
sıvama altın sürülmüş geniş bir iç pervaz ve iki yandan, tahrirleri sarı altınlı ve zeminlerine gümüşs sürülmüş iri yapraklı bir dış pervaz çevrelemektedir.

Değerlendirme: Metinde yer alan sûre başlıkları, sarı, kırmızı, mavi, yeşil, pembe gibi çeşitli renkte ipliklerle çevrilidir. Duraklar sıvama altın zeminli olup, şeşhaneli durak şeklindedir. Keşide üstleri boş bırakılmıştır. Güller üçlü, dörtlü, beşli ve altılı yıldız formunda ve servi ağacı şeklinde uzayan bir görünüş sergilemektedir. Hâtime sayfası, açık yeşil boyanmış zemin üzerine kırmızı renkte iri çiçeklerle doldurulmuştur. Mushaf-ı Şerîf'in bezeme tarzı, paftaların biçimleri ve bunların düzenlenmesi açısından klasik bezeme tarzı özelliklerini yansitmakta olsa da, bezemelerde kaba ve bozuk bir işçilik hâkimdir. Boya ve altın dengesinin orantısız oluşu, kullanılan renklerin çok çeşitliliği ve özentisiz bir işçiliğin kullanılmış olması açılarından yaklaşıldığında, Mushaf-1 Şerîf'in XIX. yüzyıl tezhip sanatının özelliklerini yansıtmakta olduğunu söyleyebiliriz.

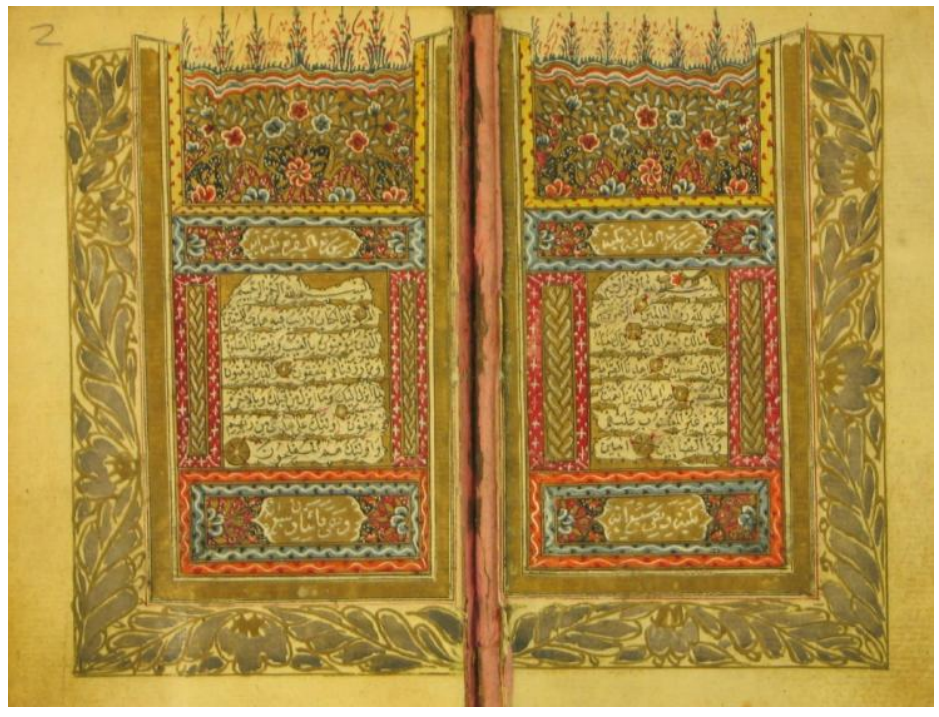

Resim 4: MHK 574 Envanter Numaralı Mushaf-1 Şerîf' in Serlevhası (45 Hk_0002)

\section{Sonuç ve Öneriler}

Manisa Yazma Eserler Kütüphanesi Müdürlüğü'nde, XIV-XIX. yüzyıllar arasına tarihlendirilen ve henüz incelemeleri bütünüyle 
tamamlanmamış toplam 53 adet Mushaf-1 Şerîf bulunmaktadır. MHK 3136, 3137 ve 5510 Envanter numaralı Mushaf-1 Şerîf'ler otuzar cüzden oluşmaktadır. 9424 Envanter numaralı ve M.1311-1312 tarihli eser, Kütüphane'de bulunan en eski tarihli Mushaf-1 Şerîf'lerden birisidir. Bezemeleri Memlûk tezhip sanatının özelliğini taşımaktadır (Pekpelvan,2010: 551-560). 3137 Envanter numaralı ve 973/1565 tarihli ile tarihsiz olan 3136 Envanter numaralı Mushaf-1 Şerîf cüzlerinin cildleri ve tezhipli bölümleri, XVI. yüzyıl özelliklerini göstermesi açısından önem taşımaktadır. Bu makalede incelenen, MHK 931 ve 9420 Envanter numaralı Mushaf-1 Şerîfler XVI yüzyıl, 3158 ve 574 Envanter numaralı Mushaf-1 Şerîfler ise, XIX. yüzyıl tezhip özelliklerini göstermektedir.

Osmanlılar döneminde, yalnızca padişah saraylarında değil, devletin en uç noktalarında da pek çok yazma eser üretilmiştir. Bu eserlerin tespit edilmesi ve gelenekli Türk sanatları alanında çalışan araştırmacılar tarafından yayın hayatına geçirilmesi gereklidir. Çalışmaların genişletilmesi ve hızlandırılmasıyla, gelenekli kitap sanatlarımızdan olan cilt, hat, ebru, tezhip vb. gibi alanlarda yeni ufuklar açılacak ve gizli kalmış kültürel değerlerimiz açığa çıkacaktır.

Ayrıca, yazma eserlerin ehliyetsiz kişiler tarafından restore edilmesi, geri dönüşü olmayan tahribatlara yol açmaktadır. Bu sebeple, sadece kitap sanatları üzerinde eğitim verecek ve uygulama yaptıracak merkezlerin açılması acilen gerekmektedir. Bunun yanı sıra, kütüphanelerde ve müzelerde yazma kitaplar hakkında araştırma yapan ve eserin aslını görmek isteyen akademisyenlere de gereken kolaylıklar gösterilmeli, kendilerine aylarca süren bir izin alma süreci yaşatılmamalıdır.

Eserlerin korunmasında gereken azami hassasiyet gösterilmeli, modern klima ve yangin sistemleri bulunmayan Türk İslâm eserleri ve arkeoloji müzelerindeki yazma eserler, T.C. Kültür ve Turizm Bakanlığı'na bağlı "Yazma Eserler Müdürlükleri” bünyesinde koruma altına alınmalıdır.

\section{Kaynakça}

Akbaş, M.- Öztekin, V.-Tansı, Ü.- Taşkapılıŏlu, M. (1991), Tezhip Sanatında Tiğg, T.C. Kültür Bakanlığı Milli Kütüphane Başkanlığı Yayınları Katalog Dizisi:1, Ankara. 
Uşak Üniversitesi Sosyal Bilimler Dergisi

$2013,6 / 3$

B. PEKPELVAN

Aksu, H. (1999), "Türk Tezhip Sanatında Süsleme Unsurları”, Osmanlı (Kültür ve Sanat), Yeni Türkiye Yayınları, Cilt:11, Ankara, 131-145.

Arseven, C. E. (Tarihsiz). Türk Sanatı, Cem Yayınevi, İstanbul.

Birol, İ. A.-Derman, Ç. (1991), Türk Tezyînî Sanatlarında Motifler, Kubealtı Akademisi Kültür ve San'at Vakfı Yayınları, İstanbul.

Derman, F. Ç. (1999), “Osmanlı Asırlarında Üslûp ve Sanatkârlarıyla Tezhip Sanatı", Osmanlı (Kültür ve Sanat),Cilt:11, Yeni Türkiye Yayınları, Ankara. 108-119.

Derman, Ç. (2002), "Mesnevî Tezhîbine Müstesnâ Bir Örnek", Birinci Uluslar arası Mevlânâ, Mesnevî ve Mevlevîhâneler Sempozyumu Bildirileri, 19-21 Aralık 2001-Manisa Mevlevîhânesi, Celal Bayar Üniversitesi Manisa Yöresi Türk Tarihi ve Kültürünü Araştırma ve Uygulama Merkezi, CBÜ Yayınları, Manisa,189-203.

Derman, Ç. (2009), “Tezhip Sanatında Kullanılan Terimler, Tabirler ve Malzeme", Hat ve Tezhip Sanatı, Editör Ali Rıza Özcan, Kültür ve Turizm Bakanlığı Yayınları, Ankara, 525-535.

Duran, G. (1999), “18. Yüzyıl Müzehhip, Çiçek Ressamı ve Lâke Üstâdı Ali Üsküdâri", Osmanlı (Kültür ve Sanat),Cilt:11, Yeni Türkiye Yayınları, Ankara, 126-130.

Güney, G. (2010), “Manisa İl Halk Kütüphanesi'ndeki Mushaf-1 Şerif Ciltlerinden Örnekler", IV. Uluslararası Türk Kültürü ile Sanatlar Kongresi/Sanat Etkinlikleri, 02-07 Kasım 2009, Kahire/Sharm El Sheikh, Selçuk Üniversitesi Selçuklu Araştırmaları Merkezi Yayınları, Konya, 561-570.

İrez, F. (1990), “Topkapı Sarayı Harem Bölümü'ndeki Rokoko Süslemenin Batılı Kaynakları", Topkapı, Yıllık:4, Topkapı Sarayı Müzesini Sevenler Derneği Yayınları, İstanbul, 21-54.

Karagöz, S. (1974), Manisa İli Kütüphaneleri, Manisa İli Merkez Kütüphaneleri Koruma Derneği Yayınları:1, Ankara.

Manisa Yazma Eserler Kütüphanesi Müdürlüğü, MHK 931; MHK 9420; MHK 3158; MHK 574.

Özen, M. E. (1998), Türk Cilt Sanatı, T. İş Bankası Yayınları No: 377 Sanat Dizisi:57, Ankara.

Özen, M. E. (1985), Yazma Kitap Sanatları Sözlüğ̈̈, İstanbul Üniversitesi Yayınları (Fen Fakültesi Döner Sermaye işletmesi), İstanbul.

Özönder, H. (2003), Ansiklopedik Hat ve Tezhip Sanatlar Deyimleri, Terimleri Sözlüğü, Sebat Ofset Matbaacılık, Konya.

Pekpelvan, B. (2010), “Manisa İl Halk Kütüphanesi'nde Bulunan 9424 Envanter Nolu Mushaf-ı Şerifin Tezhip Sanatı Açısından 
Uşak Üniversitesi Sosyal Bilimler Dergisi

$2013,6 / 3$

B. PEKPELVAN

Değerlendirilmesi", IV. Uluslar arası Türk Kültürü ile Sanatları Kongresi/Sanat Etkinlikleri, 02-07 Kasım 2009, Kahire/Sharm El Sheikh, Selçuk Üniversitesi Selçuklu Araştırmaları Merkezi Yayınları, Konya, 551-560.

Su, K. (1982), Manisa Yöresinde İşgal Avcıları, T.C. Kültür ve Turizm Bakanlığı Yayınlar1: 509, Kültür Eserleri Dizisi: 21, Ankara.

Tanındı, Z. (2003), "Kitap ve Tezhibi", Osmanlı Uygarlı̆̆ı, Cilt:2, Kültür Bakanlığı Yayınları, İstanbul, 865-891.

Tanındı, Z. (1999), "Osmanlı Sanatında Cilt”, Osmanlı (Kültür ve Sanat), Cilt:11, Yeni Türkiye Yayınları, Ankara, 103-107.

Uluçay, M. Ç. (1946), Manisa Ünlüleri, Manisa Lisesi Yayınları:2, Manisa.

Ülker, M. (1997), "Delailü'l-Hayrât", Antik-Dekor, Sayı: 38, Antik AŞ. Yayınları, İstanbul, 128-130.

www.turkislamsanatlari.com 